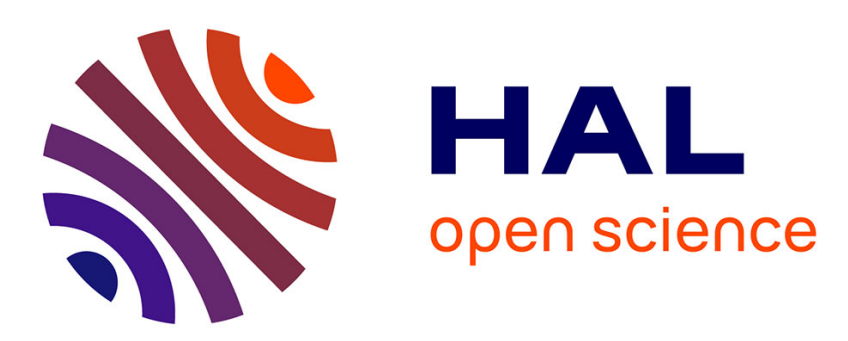

\title{
Physiological recovery from episodic acid stress does not mean population recovery of Gammarus fossarum
}

\author{
V. Felten, J.M. Baudoin, F. Guerold
}

\section{To cite this version:}

V. Felten, J.M. Baudoin, F. Guerold. Physiological recovery from episodic acid stress does not mean population recovery of Gammarus fossarum. Chemosphere, 2006, 65, p. 988 - p. 998. 10.1016/j.chemosphere.2006.03.059 . hal-00452245

\section{HAL Id: hal-00452245 \\ https://hal.science/hal-00452245}

Submitted on 1 Feb 2010

HAL is a multi-disciplinary open access archive for the deposit and dissemination of scientific research documents, whether they are published or not. The documents may come from teaching and research institutions in France or abroad, or from public or private research centers.
L'archive ouverte pluridisciplinaire HAL, est destinée au dépôt et à la diffusion de documents scientifiques de niveau recherche, publiés ou non, émanant des établissements d'enseignement et de recherche français ou étrangers, des laboratoires publics ou privés. 
Author-produced version of the article published in Chemosphère, 2006, 65, 988-998.

The original publication is available at http://www.sciencedirect.com/ doi : 10.1016/j.chemosphere.2006.03.059 


\section{Physiological recovery from episodic acid stress does not mean}

\section{2 population recovery of Gammarus fossarum}

3 V. Felten ${ }^{\mathrm{a}}$, J.M. Baudoin ${ }^{\mathrm{b}}$ \& F. Guérold ${ }^{\mathrm{c}}$.

$4{ }^{a}$ Laboratoire d'écotoxicologie, CEMAGREF, 3 bis quai Chauveau, 69336 Lyon, CP 220, 5 Cedex 09, France.

$6 \quad{ }^{\mathrm{b}}$ Laboratoire Biodiversité et Fonctionnement des Ecosystèmes, Université de Metz, Campus 7 Bridoux, Rue du Général Delestraint, 57070 Metz, France.

${ }^{c}$ Laboratoire Ecotoxicité et Santé Environnementale, CNRS UMR 7146, Université Paul Verlaine - Metz Rue du Général Délestraint, 57070 Metz, France.

\section{Abstract}

The physiological responses of the acid-sensitive amphipod Gammarus fossarum exposed in situ to acid stress ( $\mathrm{pH} 4.5$ and 5.5) and then transferred back to neutral water were investigated. Survival rate and haemolymph $\left[\mathrm{Cl}^{-}\right]$and $\left[\mathrm{Na}^{+}\right]$were assessed after 24,48 and $72 \mathrm{~h}$ of exposure in acidic streams and after a recovery period of 12, 24, 36, 48 and $60 \mathrm{~h}$. After 24h, exposure to slightly acidic $(\mathrm{pH} \mathrm{5.5)} \mathrm{and} \mathrm{strongly} \mathrm{acidic} \mathrm{water}(\mathrm{pH} 4.5)$ led to a severe and significant depletion in haemolymph $\left[\mathrm{Na}^{+}\right]$and $\left[\mathrm{Cl}^{-}\right]$compared to organisms exposed in circumneutral water ( $\mathrm{pH} 7.3)$. However, after only a $12 \mathrm{~h}$ - period of transfer back in neutral water and whatever the previous exposure time $(24,48$ and $72 \mathrm{~h})$ in both slightly and strongly acidic water, haemolymph $\left[\mathrm{Na}^{+}\right]$and $\left[\mathrm{Cl}^{-}\right]$were equal or superior to the control level without associated mortality. In spite of this fast physiological recovery capacity, populations of $G$.

23 fossarum living in streams undergoing episodic acid stresses were drastically affected thus, demonstrating the high acid-sensitivity of this species. We discuss the possible reasons of population regression and the absence of population recovery. 
Keywords: Gammarus fossarum, haemolymph, ion loss, acid stress, recovery, in situ exposure.

\section{INTRODUCTION}

Acidification of freshwater ecosystems related to anthropogenic emissions of $\mathrm{SO}_{2}$ and $\mathrm{NO}_{\mathrm{X}}$ has been one of the most striking ecological problems throughout the northern hemisphere during the 20th century. National and international legislation in the 1980s and 1990s aimed to reduce the emissions of acidifying pollutants (e.g. Clean Air Act in the USA and the Convention on Long-Range Transboundary Air Pollution in Europe) have led to the decline in acidic depositions across wide areas of Europe and North America (Stoddard et al., 1999; Lawrence et al., 2000; Likens et al., 2001). Several recent studies have shown that recovery of alkalinity has occurred in many areas of Europe and North America (Stoddard et al., 1999; Skjelkvale et al., 2001), but acidification of freshwater ecosystems still occurs in many areas (Guérold et al., 2000; Driscoll et al., 2001; Evans et al., 2001). In addition, acidification of aquatic ecosystems is now reported across other large areas of the world where high economic and demographic growth rates occur, such as in China (Thorjørn et al., 1999; Tang et al., 2001) and India (Aggarwal et al., 2001).

Episodic acidification following snowmelt or heavy rainfalls has been well documented (Ormerod \& Jenkins, 1994; O’Brien \& Eshleman, 1995; Wigington et al., 1996). These hydrometeorological events induce a decrease of $\mathrm{pH}$, Acid Neutralizing Capacity (ANC), and base cations concentrations as well as an increase of aluminum concentrations (O'Brien et al., 1993; Soulsby, 1995). The intensity of acid-stress tends to be greater in more acidic environments because low ANC streams can be subject to episodic acidic stress throughout the year (Colin et al., 1989). Change in Al speciation accompanying large $\mathrm{pH}$ depressions has 
51 been shown to cause stress and mortality in many aquatic species (Weatherley \& Ormerod, 1991; Carline et al., 1992; Van Sickle et al., 1996).

One of the most striking consequences of freshwater acidification is the erosion of biodiversity (Muniz, 1991). Numerous studies have clearly demonstrated a failure to regulate blood or haemolymph $\mathrm{Na}^{+}$and $\mathrm{Cl}^{-}$levels in acid-stressed fish, clams (Unionidae) and decapods (Massabuau, 1985; McMahon \& Stuart,- 1989; Pynnönen, 1991; Masson et al., 2002). However, most of the studies have focused on large species, and relatively little is known about physiological responses in smaller acid-sensitive species of macroinvertebrates.

Crustaceans contain many of the most acid-sensitive macroinvertebrate species (Sutcliffe \& Carrick, 1973; Guerold et al., 2000). In previous studies, Felten \& Guérold (2001, 2004) showed that Gammarus fossarum (Crustacea: Amphipoda) also suffered a severe depletion of haemolymph $\mathrm{Na}^{+}$and $\mathrm{Cl}^{-}$ions when exposed to acidic conditions. Conjointly, we determined relationship between acidification level and haemolymph ion losses. Thus, we proposed that haemolymph ion concentrations in the acid-sensitive species G. fossarum could represent effective biomarkers for monitoring acidification of running waters.

The present study aims to investigate the recovery of haemolymph $\left[\mathrm{Na}^{+}\right]$and $\left[\mathrm{Cl}^{-}\right]$in $G$. fossarum previously exposed to different magnitudes of acid stresses. In this context we assessed in situ the short-term response of haemolymph $\left[\mathrm{Na}^{+}\right]$and $\left[\mathrm{Cl}^{-}\right]$in $G$. fossarum transferred to 3 headwater streams providing 3 different acidification levels (defined by: $\mathrm{pH}$, ANC, $\left[\mathrm{Mg}^{2+}\right],\left[\mathrm{Ca}^{2+}\right]$ and $\left.\left[\mathrm{Al}_{\mathrm{tot}}\right]\right)$. For each stream and each exposure time, organisms were transferred back to their native circumneutral stream not only to test for G. fossarum recovery capacity but also to evaluate the effect of an episodic acid stress. 
Study organisms. Experiments were performed on Gammarus fossarum because this species presents several interesting characteristics for ecotoxicological investigations : 1) it is an acid-sensitive species (Guérold et al., 2000), 2) widespread and common in West Paleartica (Barnard \& Barnard, 1983), 3) often occuring in high density, 4) easy to identify to species level, 5) characterised by a sexual dimorphism and (6) playing a major role in the leaf litter breakdown process and consequently in the entire food web (Pöckl, 1995).

Experimental design. The study was conducted in the Vosges Mountains (north-eastern France) in 3 headwater streams draining sandstone bedrock and providing exposure to a range of acidification levels (Fig.1., neutral : La Maix; Ravine: slightly acidified; Gentil Sapin: strongly acidified). The 3 sites were located in the same area, the highest distance between 2 sites being less that $10 \mathrm{~km}$ representing a $20 \mathrm{mn}$ transport of the organisms.

Males G. fossarum with 8-10mm body size were collected from the neutral stream, La Maix. The experimental design we used is shown in Fig. 2.. Each Plexiglas flow-through enclosure (experimental unit) contained 144 G. fossarum. Enclosures were divided in 18 compartments with 8 individual each. Two enclosures like this were placed in each river. Enclosures were then transferred to each of the 3 streams including the neutral streams. The total number of $G$. fossarum collected for this experiment was 2592.

For each stream, one enclosure was used for haemolymph analyses and the other for the assessment of survival. For each stream, there were 3 pairs of enclosure each corresponding to one exposure time (24, 48 and $72 \mathrm{~h})$.

In order to evaluate the initial concentrations of haemolymph $\mathrm{Cl}^{-}$and $\mathrm{Na}^{+}$in G. fossarum, 12 organisms were sampled in the neutral "native" stream just before the onset of the experiments ( $\mathrm{T}_{\mathrm{o}}$, control). At 24, 48 and $72 \mathrm{~h}$ of exposure, survival was assessed and samples of haemolymph from 8 organisms were randomly collected in each stream for analysis (in 
101 enclosure corresponding to exposure time). For more details concerning the enclosure 102 protocol see Felten \& Guérold (2004).

103 After each exposure time, the sampling enclosures were transferred to the circumneutral

104 stream (La Maix) in order to initiate the recovery experiment (Fig 2.b.); the latest values of 105 haemolymph $\left[\mathrm{Cl}^{-}\right]$and $\left[\mathrm{Na}^{+}\right]$recorded before the transfer to circumneutral water were referred 106 as $t_{\mathrm{o}}$ for the recovery experiment. After $12,24,36,48$ and $60 \mathrm{~h}$ of recovery, the survival was 107 assessed and samples of haemolymph from 8 organisms were randomly collected for analysis 108 in each enclosure corresponding to each stream exposure time (Fig 2.b.).

109 Survival rates calculated for the recovery period are based on the number of organisms 110 remaining (in the enclosure) at the time of transfer to the circumneutral stream. Thus, there 111 was a 60 h-recovery kinetic for each exposure type (circumneutral, slightly acid and strongly 112 acid).

113 Survival, haemolymph sampling and analysis. For each acid exposure time and recovery

114 time, the survival was assessed in each stream (3 replicates of 48 organisms). Samples of 115 haemolymph $(0.8$ to $1.2 \mu \mathrm{l})$ were taken from the telson of each individual $(\mathrm{n}=8)$ using a 116 microsyringe, transferred to a gauged 5- $\mu 1$ microcapillary tube and centrifuged for $10 \mathrm{~min}$ at $1176596 \mathrm{~g}$. After centrifugation the liquid phase was diluted in $2 \mathrm{ml}$ of Nanopur water to 118 determine chloride and sodium concentrations in haemolymph by ionic chromatography 119 (Dionex 4500i with Ion Pac AS4A column) and atomic absorption spectrophotometry (AAS)

120 (Perkin Elmer Analyst 100), respectively.

121 Water analysis. Water samples were collected at the initiation of the experiment $\left(\mathrm{T}_{\mathrm{o}}\right)$ and at 122 each time of acid exposure (24, 48 and $72 \mathrm{~h})$ and recovery (12, 24, 36, 48 and $60 \mathrm{~h})$. Cations 123 were analysed by flame AAS and anions by ionic chromatography as described previously.

124 Total aluminium was determined by graphite furnace AAS (Varian Spectraa 300) after 125 acidification with $0.25 \% \mathrm{HNO}_{3}$. Acid neutralising capacity (ANC) was measured by Gran's 
126 titration and $\mathrm{pH}$ (glass electrode), and conductivity with multi-parametric equipment (WTW).

127 Chemical characteristics of water from each stream are given in Table $\mathbf{1}$.

128 Statistical analysis. All data are reported as mean \pm SD. Statistical comparisons of 129 experimental data were performed by two-way analysis of variance (ANOVA) and Ficher's 130 Least Significant Difference test (LSD). The analyses were carried out using STATISTICA 131 (Microsoft), with a probability limit of $\mathrm{p} \leq 0.05$ considered as significant.

\section{Acid exposure}

135 Acidified streams were characterized by low $\mathrm{pH}$, low $\mathrm{ANC}$, low $\left[\mathrm{Mg}^{2+}\right]$ and low $\left[\mathrm{Ca}^{2+}\right]$ and 136 high $\left[\mathrm{Al}_{\text {tot }}\right]$ (Table 1). The baseline levels of haemolymph $\left[\mathrm{Cl}^{-}\right]$and $\left[\mathrm{Na}^{+}\right]$prior to the 137 exposure were $54.1 \pm 8.1$ and $90.4 \pm 15.9 \mathrm{mmol} \mathrm{l}^{-1}$, respectively, in control organisms (Fig. 138 2.a.-b.).

139 The 2-way analysis of variance (ANOVA) indicated that stream acidity, exposure time and

140 the interaction between them (Stream $\times$ Exposure Time) exerted a significant effect on 141 haemolymph parameters ([Na $\left.\left.{ }^{+}\right],\left[\mathrm{Cl}^{-}\right]\right)$and survival (Table 2.a.).

142 Haemolymph $\left[\mathrm{Na}^{+}\right]$and $\left[\mathrm{Cl}^{-}\right]$in $G$. fossarum exposed to circumneutral stream remained 143 constant over a 72-h exposure period, but decreased significantly in organisms exposed to 144 slightly acidic (Ravine, mean $\mathrm{pH}=5.5)$ and strongly acidic streams (Gentil Sapin, mean $\mathrm{pH}=$ 145 4.5) during the first $24 \mathrm{~h}$ (Fig. 3.a.-b.). Indeed, after $24 \mathrm{~h}$ of exposure, the loss of 146 haemolymph $\mathrm{Cl}^{-}$ranged from $22.5 \%$ in the slightly acidic stream (mean haemolymph $\left[\mathrm{Cl}^{-}\right]=$ $14741.9 \pm 6.7 \mathrm{mmol} \mathrm{l}^{-1}$ ) to $48.8 \%$ in the strongly acidic one (mean haemolymph $\mathrm{Cl}^{-}=27.7 \pm 5.5$

$148 \mathrm{mmol} \mathrm{l^{-1 }}$ ) compared with the control (mean haemolymph $\left.\mathrm{Cl}^{-}=54.1 \pm 8.1 \mathrm{mmol} \mathrm{l}^{-1}\right)($ Fig.

149 3.a.). The same trend was observed for haemolymph $\left[\mathrm{Na}^{+}\right]$. After $24 \mathrm{~h}$ of exposure, the loss of 150 haemolymph $\mathrm{Na}^{+}$ranged from $19.9 \%$ in Ravine (mean haemolymph $\mathrm{Na}^{+}=72.4 \pm 13.6 \mathrm{mmol}$ 
$151 \mathrm{1}^{-1}$ ) to $53.9 \%$ in Gentil Sapin (mean haemolymph $\mathrm{Na}^{+}=41.7 \pm 9.6 \mathrm{mmol} \mathrm{l}^{-1}$ ) compared with

152 the control (mean haemolymph $\mathrm{Na}^{+}=90.4 \pm 15.9 \mathrm{mmol} \mathrm{l}^{-1}$ ) (Fig. 3.b.).

153 After $48 \mathrm{~h}$ of exposure, the haemolymph $\left[\mathrm{Na}^{+}\right]$and $\left[\mathrm{Cl}^{-}\right]$of the organisms exposed to slightly 154 and strongly acidic streams were close to $24 \mathrm{~h}$-exposure values and remained constant until the 155 end of the experiment. Individuals transferred for $72 \mathrm{~h}$ to Ravine had a mean haemolymph $156\left[\mathrm{Cl}^{-}\right]$of $42 \pm 11.5 \mathrm{mmol} \mathrm{l}^{-1}$ and $\left[\mathrm{Na}^{+}\right]$of $70.8 \pm 20 \mathrm{mmol} \mathrm{l}^{-1}$, representing a significant $22.3 \%$ 157 loss of chloride and a significant $21.7 \%$ loss of sodium $(\mathrm{p}<0.05)$. On the other hand, 158 individuals transferred for $72 \mathrm{~h}$ to Gentil Sapin had a haemolymph $\left[\mathrm{Cl}^{-}\right]$of $25.6 \pm 4.6 \mathrm{mmol}^{-1}$ 159 and $\left[\mathrm{Na}^{+}\right]$of $44.7 \pm 6.9 \mathrm{mmol} \mathrm{l}^{-1}$, representing a chloride loss of $45.3 \%$ and a sodium loss of $16050.5(\mathrm{p}<0.001)$.

161 For each exposure time, the survival rate in $G$. fossarum transferred to the native circumneutral stream (La Maix) remained very high and above 99\%. After $72 \mathrm{~h}$ of exposure,

163 the survival rates in organisms exposed to slightly and strongly acidic streams were 164 significantly different from mean control values for the same exposure time $(\mathrm{p}<0.05)$, 165 reaching $89.6 \pm 7.5 \%$ and $42.4 \pm 11.9 \%$ respectively. On the contrary the survival rates after 16624 and $48 \mathrm{~h}$ of exposure in slightly acidified streams (Ravine) were not significantly different 167 from those observed in the neutral stream whereas significant differences were measured in 168 organisms transferred to strongly acidified stream (Gentil sapin). Thus, survival rates of 169 gammarids transferred to Gentil sapin reached $79.9 \pm 11.8 \%$ and $51.7 \pm 10.8 \%$ after a $24 \mathrm{~h}$ and 170 a 48h-exposure time respectively (Fig. 3.c.).

173 The 2-way analysis of variance (ANOVA) indicated that Exposure Time and/or Recovery

174 Time as well as the interaction term had a significant influence on haemolymph $\left[\mathrm{Na}^{+}\right]$, 175 haemolymph $\left[\mathrm{Cl}^{-}\right]$and survival (Table 2.b.). 
176 We observed a rapid and total recovery of haemolymph $\left[\mathrm{Cl}^{-}\right]$and $\left[\mathrm{Na}^{+}\right]$in organisms

177 previously exposed to slightly and strongly acidic stream. After only $12 \mathrm{~h}$ transferred back in

178 the native circumneutral stream, the mean values of haemolymph parameters were similar or

179 significantly higher than those measured at To (Fig. 4.a.-b. and Fig. 5. a.-b.).

180 After a 12h-recovery in La Maix following a 72h-exposure in Gentil sapin (the longest and 181 most intense acid stress tested), the mean haemolymph $\left[\mathrm{Cl}^{-}\right]$increased from $29.6 \pm 4.3 \mathrm{mmol}$

$182 \mathrm{l}^{-1}$ to $63.8 \pm 13.9 \mathrm{mmol} \mathrm{\textrm {l } ^ { - 1 }}$, representing an increase of $115.6 \%$. Similarly the mean 183 haemolymph $\left[\mathrm{Na}^{+}\right]$increased from $44.7 \pm 6.9 \mathrm{mmol} \mathrm{l}^{-1}$ to $85.2 \pm 8.5 \mathrm{mmol} \mathrm{l}^{-1}$, representing an 184 increase of $90.6 \%$.

185 In all enclosures, the survival rates remained high throughout the recovery experiment ( $>93 \%$, 186 Fig. 4.c. and Fig. 5 .c.).

\section{DISCUSSION}

\section{Acid-exposure}

190 Several studies have shown that crustaceans exposed to water-borne pollutants, environmental

191 stressors and pathological agents usually exhibit disruption of ionic regulation (Lignot et al., 192 2000). Different causes include alterations in the structure and ultrastructure of the branchial 193 and excretory organs, and changes in $\mathrm{Na}^{+}, \mathrm{K}^{+}$-ATPase activity, ion fluxes and surface 194 permeability (Lignot et al., 2000). Ion-regulation failure leading to a severe deficiency of 195 extracellular ions (i.e. $\mathrm{Na}^{+}$and $\mathrm{Cl}^{-}$) has been recognised to be the major response in fish to 196 acid stress (McDonald et al., 1989; Potts \& McWilliams, 1989; Wood, 1989). Similar results 197 have been reported in crayfish (Appelberg, 1985; Fjeld et al., 1988; McMahon \& Stuart, 198 1989; Jensen \& Malte, 1990), gammarids (Rupprecht, 1992; Felten \& Guérold, 2001, 2004) 199 and molluscs (Pynnönen, 1991). Surprisingly, and despite the numerous papers reporting 200 detrimental effects of acidification on invertebrate communities, few studies have been 
201 performed on the ecophysiology of smaller acid-sensitive macroinvertebrate species 202 (Herrmann, 1987; Herrmann \& Andersson, 1986).

203 In the present study we showed that exposure of G. fossarum to strongly acidic or slightly 204 acidic water induced early significant losses of haemolymph $\left[\mathrm{Na}^{+}\right]$and $\left[\mathrm{Cl}^{-}\right]$. Moreover, 205 failure in ion-regulation was accompanied by a significant mortality. These results were in 206 agreement with those obtained in previous studies (Felten \& Guérold, 2001, 2004) which 207 permitted us to demonstrate that ion losses were significantly correlated to $\mathrm{pH}$.

\section{Recovery from acid stress}

210 Despite drastic ion losses $\left(\mathrm{Cl}^{-}\right.$and $\left.\mathrm{Na}^{+}\right)$following exposures to slightly and strongly acidic 211 stresses, organisms transferred back to the native circumneutral stream were surprisingly able to recover rapidly from acid stress (as soon as $12 \mathrm{~h}$ ). Moreover, survival rates associated with

213 the recovery period were very high (>93.4\%). Consequently, the ion-regulation failure 214 evidenced during the exposure under acidic conditions appears reversible even when the loss 215 of ions was severe $(>50 \%)$.

216 These results are in accordance with those of several studies which have highlighted the 217 recovery capacity of several acid-sensitive species following their transfer from an acidified 218 medium to a circumneutral medium. Favrel (1998) observed a total recovery of haemolymph $219\left[\mathrm{Cl}^{-}\right]$and $\left[\mathrm{Na}^{+}\right]$in Dinocras cephalotes (Plecoptera) after 16 days of recovery in a 220 circumneutral water $\left(\mathrm{pH}=6.6,[\mathrm{Al}]=10 \mu \mathrm{g} \mathrm{1^{-1 }}\right)$ following a 8 days exposure in an acidified 221 water $\left(\mathrm{pH}=4.6,[\mathrm{Al}]=540 \mu \mathrm{g} \mathrm{l}^{-1}\right)$. Comparable results had been also reported for Anodonta anatina (Mollusc) for a 8 day exposure to $\mathrm{pH} 4.0-5.0$ followed by a 8 days transfer in a water with a pH 7.2-7.4 (Pynnönen, 1994). Similary, Kroglund \& Staurnes (1999) conducted an 224 experiment showing that acid-exposed (pH 6.0 and 5.6) Salmo salar smolts were able to re225 establish their plasma chloride levels within 3 days in $\mathrm{pH} 6.28$ water, but the authors did not 
sample organisms until the end of the 3 days. In our study, the recovery observed for $G$.

fossarum was definitely faster than those observed in the species mentioned above.

Moreover, these results are in accordance with our previous observation (Felten \& Guérold, 2004) showing the physiological adaptation of G. fossarum exposed to slightly acidic stress $\left(\mathrm{pH} 5.7,\left[\mathrm{Al}_{\mathrm{tot}}\right]=2.5 \mu \mathrm{mol} 1^{-1},\left[\mathrm{Ca}^{2+}\right]=26.8 \mu \mathrm{mol} 1^{-1}\right)$. After $24 \mathrm{~h}$ of exposure, G. fossarum had 231 undergone significant ion losses but following 96h, no differences were observed in 232 haemolymph $\left[\mathrm{Cl}^{-}\right]$and $\left[\mathrm{Na}^{+}\right]$(compared to the control) without any additional mortality.

233 Several assumptions may be advanced to explain the fast recovery of haemolymph $\left[\mathrm{Cl}^{-}\right]$and $234\left[\mathrm{Na}^{+}\right]$. On the one hand Chamier et al. (1989) reported that $\mathrm{Na}^{+}$turnover is very fast in $G$. 235 pulex $\left(65 \%\right.$ of total body in $\mathrm{Na}^{+}$per day at $\left.9^{\circ} \mathrm{C}\right)$. In addition, Wood \& Ronago (1986) 236 observed an increase in $\mathrm{Cl}^{-}$and $\mathrm{Na}^{+}$uptake during the recovery following an exposure to $\mathrm{pH} 4$. 237 This can be due to a reduction of the $\left[\mathrm{H}^{+}\right] /\left[\mathrm{Na}^{+}\right]$ratio in water, consequently decreasing the 238 competition between these two ions at ionic transport sites, leading to an increase in $\mathrm{Na}^{+}$ 239 uptake. In addition organisms transferred back to circumneutral waters were then facing lower 240 passive ion losses and water uptake because of the increase in $\left[\mathrm{Ca}^{2+}\right] /[\mathrm{Al}]$ and $\left[\mathrm{Ca}^{2+}\right] /\left[\mathrm{H}^{+}\right]$ 241 ratios. Thus, the easier access to $\mathrm{Ca}^{2+}$ allowed the reinforcement of cellular junctions allowing 242 reduced permeability. Finally, different studies have shown an increased number of chloride 243 cells in gills as well as morphological changes in the apical surface of these chloride cells, in 244 various species of fish exposed to acid water (Chevalier et al., 1985; Karlsson-Norrgren et al., 245 1986; Jagoe \& Haines, 1990, 1997). For example, chloride cells can present apical wells 246 (Leino \& McCormick, 1984; Leino et al., 1987a, 1987b) or apical evaginations (Chevalier et 247 al., 1985; Leino et al., 1987a, 1987b) increasing exchange surface. This kind of change which 248 can limit and/or offset ion losses under acidic conditions, could explain the fast recovery of 249 haemolymph $\mathrm{Na}^{+}$and $\mathrm{Cl}^{-}$concentrations after a transfer back to circumneutral water. 
However, to our knowledge, no study has highlighted such modifications in small macroinvertebrate species.

\section{Extrapolation for populations}

In a previous study (Felten, 2003), populations of G. fossarum were sampled using a surber sampler, on 10 occasions and in 3 sites of the same circumneutral stream (La Maix). This stream was characterized by a decreasing gradient of acidification from upstream to downstream (the most distant sites were $2.7 \mathrm{~km}$ apart). The most downstream site, studied in this paper, was circumneutral throughout the year (mean $\mathrm{pH}: 7$; from 6.7 to $7.4 ; \mathrm{n}=25$ ). The most upstream site was affected by episodic strong acidification events (mean $\mathrm{pH}$ : 6.0; from 4.3 to $6.80 ; \mathrm{n}=25$ ) whereas slightly episodic stresses occurred in the intermediate site (mean $\mathrm{pH}: 6.6$; from 5.7 to $7 ; \mathrm{n}=25$ ). As a result, G. fossarum was totally absent from the upper site and, at the intermediate site, the density of the species was 10 times lower (443 ind. $/ \mathrm{m}^{2}$ ) that those observed downstream (4317 ind. $\left./ \mathrm{m}^{2}\right)$. Consequently, although $G$. fossarum was able to rapidly compensate high ion losses caused by acid stress, gammarid population was drastically affected by repeated episodic acid stress meaning that the rapid compensation of high ion loss seems not to help the G. fossarum population in surviving acid episodes if these are repeated.

Episodic acidification has been recognized to exert a drastic impact on macroinvertebrate and fish populations and communities (Weatherley \& Osmerod, 1991 ; Baker et al., 1996 ; Van Sickle et al., 1996; Lepori et al., 2003). McCahon \& Poulton (1991) and Merrett et al. (1991) showed the cumulative effect of multiple acid stresses on macroinvertebrate mortality. Finally, several studies conclude that acid episodes can restrict or offset the recovery process of acid sensitive invertebrates (Kowalik et al., 2006) and fish (Kroglund et al., 2001). 
274 According to Davies et al. (1992), episodic acidifications take place over hours (rainfall) to 275 months (snowmelt). In a previous experiment, Felten \& Guérold (2005) showed that a 168h276 exposure of G. fossarum to Gentil sapin streamwater led to $80 \%$ of mortality which can 277 explain the total absence of the specie in the upper site.

278 Several non exclusive hypotheses can conjointly explain the decrease of density or the loss of 279 population in streams subjected to episodic acid stresses, such as $i$ ) an increase of drift280 response and mortality of sensitive stages (juveniles) (McCahon \& Poulton, 1991; Taylor et 281 al., 1994), ii) a lower food quality (Willoughby, 1988; Willoughby \& Mappin, 1988; Sutcliffe 282 \& Hildrew, 1989) or/and a lower conversion efficiency of food to growth (Lee et al., 1983; 283 Hargeby \& Petersen, 1988), iii) a lower food intake (Lemly \& Smith, 1985; Tierney \& 284 Atema, 1986), iv) an enhanced energetic cost associated with osmoregulation, ion retention 285 and respiration (Økland \& Økland, 1986) leading to a decrease of growth and reproduction 286 (Maltby, 1994; Seiler \& Turner, 2004).

287 Moult is known to be a critical phase for crustaceans (Wright \& Frain, 1981; McCahon \& 288 Pascoe, 1988; Wheatly \& Gannon, 1995) requiring a lot of energy (Maltby, 1994; Wheatly \& 289 Gannon, 1995). According to Pöckl (1992), in younger gammarid stages, moult occurred 290 close together. Consequently, a higher acid-sensitivity of younger stages (Naylor et al., 1990) explained by the moult frequency could partly account for population regression in acidified streams. Moreover, small-sized gammarids affected by an acid stress may be unable to resist 293 to the associated hydrological stress.

\section{Conclusion}

296 G. fossarum facing acid stress fail to regulate ion losses, leading thus to an important mortality when the environmental stress is intense. This failure is rapidly reversible when the 
299 losses following acid stress, populations have been severely reduced or have totally 300 disappeared from numerous headwater streams draining catchments subject to acidification.

301 Thus, it is suggested that both the frequency and the intensity of stresses clearly structure 302 gammarid population. In this context, we recommend to conduct further studies dealing with 303 the effects of episodic acidification on population structure, in relation to physiological 304 parameters (e.g. energetic cost, growth) to better understand population regression and 305 recovery. This kind of study is particularly important since the decline of base cations (mainly $306 \mathrm{Ca}^{2+}$ and $\mathrm{Mg}^{2+}$ ) in soils and surface waters has been reported in most areas where high rates of 307 sulphur depositions occurred previously. These trends should indeed lead to an increase of 308 episodic acid stress frequency and intensity.

310 Acknowledgements. We would like to thank Crane Rogers for linguistic corrections of this 311 manuscript.

315 Aggarwal, S.G., Chandrawanshi, K., Patel, R.M., Agarwal, S., Kamavishdar, A., Mundhara, G., 2001. Acidification of surface water in central India. Water Air Soil Poll. 130, 855-862. 317 Appelberg, M., 1985. Changes in haemolymph ion concentrations of Astacus astacus L. and 318 Pacifastacus leniusculus (Dana) after exposure to low $\mathrm{pH}$ and aluminum. Hydrobiologia $319 \quad 121,19-25$.

320 Barnard, J.L., Barnard, C.M., 1983. Freshwater Amphipoda of the World (Parts I \& II). Hayfield Associates, Mt. Vernon. 
Episodic acidification of small streams in the northeastern United States: Effet on fish populations. Ecol. Appl. 6 (2), 422-437.

326 Carline, R.F., DeWalle, D.R., Sharpe, W.E., Dempsey, B.A., Gagen, C.J., Swistock, B., 1992. Water chemistry and fish community responses to episodic stream acidification in Pennsylvania, U.S.A. Environ. Pollut. 78, 45-48.

Chamier, A.C., Sutcliffe, D.W., Lishman, J.P., 1989. Changes in Na, K, Ca, Mg, and Al content of submersed leaf litter, related to ingestion by the amphipod Gammarus pulex (L.). Freshwater Biol. 21, 181-189.

Chevalier, G., Gauthier, L., Moreau, G., 1985. Histopathological and electron microscopic studies of gills of brook trout, Salvelinus fontinalis, from the acidified lakes. Can. J. Zool. 63, 2062-2070.

Colin, J.L., Renard, D., Lescoat, V., Jaffrezo, J.L., Gros, J.M., Strauss, B., 1989. Relationship between rain and snow acidity and air mass trajectory in Eastern France. Atmos. Environ. $23(7), 1487-1498$.

Davies, T.D., Tranter, M., Wigington, P.J., \& Eshleman K.N., 1992. 'Acidic episodes' in surface waters in Europe. Journal of Hydrology, 132, 25-69.

340 Driscoll, C.T., Lawrence, G.B., Bulger, A.J., Butler, T.J., Cronan, C.S., Eagar, C., Lambert, 341 K.F., Likens, G.E., Stoddard, J.L., and Weathers, K.C., 2001. Acidic deposition in the northeastern United States: Sources and inputs, ecosystem effects, and management strategies. BioScience 51, 180-198.

344 Evans, C.D., Harriman, R., Monteih, D.T., Jenkins, A., 2001. Assessing the suitability of acid neutralizing capacity as a measure of long-term trends in acidic waters based on two parallel datasets. Water Air Soil Poll. 130, 1541-1546.

347 Favrel, C., 1998. Ecophysiologie de la larve de Dinocras cephalotes (Plecoptère, Perlidé) 348 exposée à un milieu acidifié, Thesis, Metz university, 279 p. 
349 Felten, V., Guerold, F., 2001. Hyperventilation and loss of hemolymph $\mathrm{Na}^{+}$and $\mathrm{Cl}^{-}$in the 350 freshwater amphipod Gammarus fossarum exposed to acid stress: a preliminary study. Dis. $351 \quad$ Aquat. Org. 45, 77-80.

352 Felten, V., 2003. Effets de l'acidification des ruisseaux vosgiens sur la biologie, l'écologie et 353 l'écophysiologie de Gammarus fossarum Koch, 1835 (Crustacea Amphipoda): Approche 354 intégrée à différents niveaux d'organisation. Thesis, Metz university, 279 p.

355 Felten, V., Guerold, F., 2004. Haemolymph $\left[\mathrm{Na}^{+}\right]$and $\left[\mathrm{Cl}^{-}\right]$loss in Gammarus fossarum exposed in situ to a wide range of acidic streams. Dis. Aquat. Org. 61, 113-121.

Fjeld, E., Hessen, D.O., Roos, N., Taubolt, T., 1988. Changes in gill ultrastructure and haemolymph chloride concentrations in the crayfish, Astacus astacus, exposed to deacidified aluminum rich water. Aquaculture 72, 139-150.

360 Guerold, F., Boudot, J.P., Jacquemin, G., Vein, D., Merlet, D., Rouiller, J., 2000. Macroinvertebrate community loss as a result of headwater stream acidification in the Vosges Mountains (N-E France). Biodivers. Conserv. 9, 767-783.

Hargeby, A., Petersen, R.C. Jn., 1988. Effects of low pH and humus on the survivorship, growth and feeding of Gammarus pulex (L.) (Amphipoda). Freshwater Biol. 19, 235-247.

Herrmann, J., Andersson K.G., 1986. Aluminium impact on respiration of lotic mayflies at low pH. Water Air Soil Poll. 30, 703-709.

Herrmann, J., 1987. Sodium levels of lotic mayfly nymphs being exposed to aluminium at low pH a preliminary report. Ann. Soc. R. Zool. de Belg. 117 (1), 181-188.

Jagoe, C.H., Haines, T.A., 1990. Morphometric effects of low pH and limed water on the gills of atlantic salmo (Salmo salar). Can. J. Fish. Aquat. Sci. 47, 2451-2460. smolts due to addition of acid and aluminum to stream water. Environ. Pollut. 97 (1-2), 137-146. 
374 Jensen, F.B., Malte, H., 1990. Acid-base and electrolyte regulation, and hemolymph gas 375 transport in crayfish Astacus astacus, exposed to soft, acid water with and without 376 aluminum. J. Comp. Physiol. B 160, 483-490.

377 Karlsson-Norrgren L., Björklund I., Ljungberg, O., Runn, P., 1986. Acid water and 378 aluminium exposure : experimentally induced gill lesions in brown trout, Salmo trutta L. J. 379 Fish Dis. 9, 11-25.

380 Kroglund F, Kaste O, Rosseland B.O., Poppe T. 2001. The Return of the Salmon. Water, Air and Soil Pollution. 130 : 1349-1354

382 Kowalik, R.A. \& Ormerod, S. J., 2006. Intensive sampling and transplantation experiments reveal continued effects of episodic acidification on sensitive stream invertebrates. Freshwater Biol. 51, 180-191.

385 Kroglund, F., Staurnes, M., 1999. Water quality requirements of smolting Atlantic salmon 386 (Salmo salar) in limed acid rivers. Can. J. Fish. Aquat. Sci. 56, 2078-2086.

387 Lawrence, G.B., Lovett, G.M., Baevsky, Y.H., 2000. Atmospheric deposition and watershed 388 nitrogen export along an elevational gradient in the Catskill Mountains, New York. 389 Biogeochemistry 50, 21-43.

390 Leino, R.L., McCormick, J.H., 1984. Morphological and morphometrical changes in chloride 391 cells of the gills of Pimephales promelas after chronic exposure to acid water. Cell. Tissue 392 Res. 236, 121-128.

393 Leino, R.L., McCormick, J.H., Jensen, K.M., 1987a. Changes in gill histology of fathead 394 minnows and yellow perch transferred to soft water or acidified soft water with particular 395 reference to chloride cells. Cell. Tissue Res. $250: 389-399$.

396 Leino, R.L., McCormick, J.H., Anderson, J.G., 1987b. Histopathological changes in the gills 397 of pearl dace, Semotilus margarita, and fathead minnows, Pimephales promelas, from 398 experimentally acidified Canadian lakes. Can. J. Fish. Aquat. Sci. 44, 126-134. 
Lepori, F., Barbieri, A., Ormerod, S. J., 2003. Effects of episodic acidification on macroinvertebrate assemblages in Swiss Alpine streams. Freshwater Biol. 48, 1873-1885.

Lignot, J.H., Spanings-Pierrot, C., Charmentier, G., 2000. Osmoregulatory capacity as a tool in monitoring the physiological condition and the effect of stress in crustaceans. Aquaculture 191, 209-245.

Lee, R.M., Gerking, S.D., Jezierska, B., 1983. Electrolyte balance and energy mobilization in acid-stressed rainbow trout Salmo gairdneri and their relation to reproductive stress. Environmental Biology of Fishes 8, 115-123.

Lemly, A.D., Smith, R.J.F., 1985. Effects of acute exposure to acidified water on the behavioural response of Fathead Minnows, Pimephales promelas, to chemical feeding stimuli. Aquat. Toxicol. 6, 625-36.

Likens, G.E., Butker, T.J., Buso, D.C., 2001. Long- and short-term changes in sulphate deposition : effects of the 1990 Clean Air Act Amendments. Biogeochemistry 52, 1-11.

Massabuau, J.C., 1985. Pluies acides et physiologie des animaux aquatiques. Bull. Soc. Ecophysiol. 10, 59-74.

McCahon, C.P., Pascoe, D., 1988. Cadmium toxicity to the freshwater amphipod Gammarus pulex (L.) during the moult cycle. Freshwater Biol. 19, 197-203.

McCahon, C.P., Poulton, M.J., 1991. Lethal and sub-lethal effects of acid, aluminium and lime on Gammarus pulex during repeated simulated episodes in a welsh stream. Freshwater Biol. 25, 169-178.

McDonald, D.G., Reader, J.P., Dalziel T.R.K., 1989. The combined effects of $\mathrm{pH}$ and trace metals on fish ionoregulation. In: Morris, R., Taylor, E.W., Brown, D.J.A., Brown, J.A. (Eds.), Acid toxicity and aquatic animals. Cambridge University Press, Cambridge, pp 221-242. 
McMahon, B.R., Stuart, S.A., 1989. The physiological problem of crayfish in acid water. In: Morris R, Taylor EW, Brown DJA \& Brown JA (Eds.), Acid toxicity and aquatic animals. Cambridge University Press, Cambridge, pp 171-200.

Maltby, L., 1994. Stress, shredders and streams: using Gammarus energetics to assess water quality. In: Sutcliffe, D.W., (Ed.), Water quality and stress indicators in marine and freshwater ecosystems : linking levels of organisation (individual, population, communities). Freshwater Biological association, Ambleside, pp 98-110.

Masson, N., Guerold, F., Dangles, O., 2002. Use of blood parameters in fish to assess acidic stress and chloride pollution in French running waters. Chemosphere 47, 467-473.

Merrett, W.J., Rutt, G.P., Weatherley, N.S., Thomas, S.P., Ormerod, S.J., 1991. The response of macroinvertebrates to low $\mathrm{pH}$ and increased aluminium concentrations in Welsh streams: multiple episodes and chronic exposure. Arch. Hydrobiol. 121, 115-125.

Muniz, I.P., 1991. Freshwater acidification: Its effects on species and communities of freshwater microbes, plants and animals. Proc. R. Soc. Edinburgh 97b, 227-254.

Naylor, C., Pindar, L., Calow, P., 1990. Inter- and intraspecific variation in sensitivity to toxins; the effects of acidity and zinc on the freshwater crustaceans Asellus aquticus (L.) and Gammarus pulex (L.). Water Res. 24 (6), 757-762.

O’Brien, A.K., Rice, K.C., Kennedy, M.M., Bricker, O., 1993. Comparison of episodic acidification of mid-atlantic upland and coastal plain stream. Water Resour. Res. 29 (9), $3029-3039$.

O’Brien, A.K., Eshleman, K.N., 1995. Episodic acidification of a costal plain stream in Virginia. Water Air Soil Poll. 89, 291-316.

Økland, J., Økland, K.A., 1986. The effects of acid deposition on benthic animals in lakes and stream. Experimentia 42, 471-486. 
447 Ormerod, S.J., Jenkins, A., 1994. The biological effect of acid episodes. In: Wright, R., 448 Steinberg, C. (Eds.), Acidification; Past, Present and Future, Dahlem Workshop, Wiley, 449 Chichester, pp 259-272.

450 Pöck1, M., 1992. Effects of temperature, age and body size on moulting and growth in the 451 freshwater amphipods Gammarus fossarum and G. roeseli. Freshwater Biol. 27, 211-225.

452 Pöckl, M., 1995. Laboratory studies on growth, feeding, moulting and mortality in the 453 freshwater amphipods Gammarus fossarum and G. roeseli. Arch. Hydrobiol. 134 (2), 223454253.

455 Potts, W.T.W., McWilliams, P.G., 1989. The effect of hydrogen and aluminum ions on fish 456 gills. In: Morris, R., Taylor, E.W., Brown, D.J.A., Brown, J.A. (Eds.), Acid toxicity and 457 aquatic animals. Cambridge University Press, Cambridge, pp 201-220

458 Pynnönen, K., 1991. Influence of aluminum and protons on the electrolyte homeostasis in the 459 Unionidae Anodonta anatina and Unio pictorum, Arch. Environ. Contam. Toxicol. 20, $460 \quad 218-225$.

461 Pynnönen, K., 1994. Hemolymph gases, acid-base status, and electrolyte concentration in the 462 freshwater clams Anodonta anatina and Unio pictorium during exposure to and recovery 463 from acidic conditions. Physiol. Zool. 67 (6), 1544-1559.

464 Rupprecht, R., 1992. Zu den ursachen der unterschiedkichen pH-Empfindlichkeit von 465 Gammarus pulex L., G. fossarum Koch (Amphipoda) und Asellus aquaticus L. (Isopoda). 466 Int. Revue ges. Hydrobiologia 77 (2), 255-264.

467 Steven, M., Seiler, S.M., Andrew, M., Turner, A.M., 2004. Growth and population size of 468 crayfish in headwater streams: individual- and higher-level consequences of acidification. $469 \quad$ Freshwater Biol. 49, 870-881.

470 Skjelkvale, B.L., Torseth, K., Aas, W., Andersen, T., 2001. Decrease in acid deposition471 recovery in Norwegian waters. Water Air Soil Poll. 130, 1433-1438. 
472 Soulsby, C., 1995. Contrasts in storm event hydrochemistry in an acidic afforested catchment 473 in upland Wales. J. Hydrol. 170, 159-179.

474 Stoddart, J.L., Jeffries, D.S., Lukewille, A., Clair, T.A., Dillon, P.J., Driscoll, C.T., Forsius, 475 M., Johannessen, M., Kahl, J.S., Kellogg, J.H., Kemp, A., Mannio, J., Monteith, D.T., 476 Murdoch, P.S., Patrick, S., Rebsdorf, A., Skjelkvale, B.L., Stainton, M.P., Traaen, T., van 477 Dam, H., Webster, K.E., Wieting, J., Wilander, A., 1999. Regional trends in aquatic 478 recovery from acidification in North America and Europe. Nature, 401 (6753), 575-578.

479 Sutcliffe, D.W., Carrick, T.R., 1973. Studies on mountain streams in the English Lake 480 District. I. PH, calcium and the distribution if invertebrates in the River Duddon. $481 \quad$ Freshwater Biol. 3, 437-462.

482 Sutcliffe, D.W., Hildrew, A.G., 1989. Invertebrate communities in acid streams. In: Morris, 483 R., Taylor, E.W., Brown, D.J.A., Brown, J.A. (Eds), Acid toxicity and aquatic animals. 484 Cambridge University Press, Cambridge, pp 13-29.

485 Tang, D., Lydersen, E., Seip, H.M., Angell, V., Eilertsen, O., Larssen, T., Liu, G., Kong, G., 486 Mulder, J., Semb, A., Solberg, S., Torseth, K., Vogt, R.D., Xiao, J., Zhao, D., 2001. 487 Integrated monitoring program on acidification of Chinese terrestrial systems (impacts) 488 A Chinese- Norwegian collaboration project. Water Air Soil Poll. 130, 1073-1078.

489 Taylor, E.J., Rees, E.M., Pascoe, D., 1994. Mortality and drift-related response of the 490 freshwater amphipod Gammarus pulex (L.) exposed to natural sediments, acidification and $491 \quad$ copper. Aquat. Toxicol. 29, 83-101.

492 Thorjørn, L., Seip, H.M., Semb, A., Mulder, J., Muniz, I., Vogt, R.D., Lydersen, E., Angell, 493 V., Tang, D., Eilertsen, O., 1999. Acid deposition and its effects in China : An overview. 494 Environmental Science \& Policy 2, 9-24. 
495 Tierney, A.J., Atema, J., 1986. Effect of acidification on the behavioural response of 496 Crayfishes (Orconectes virilis and Procambarus acutus) to chemical stimuli. Aquat. 497 Toxicol. 9, 1-11.

498 Van Sickle, J., Baker, J.P., Simonin, H.A., Baldigo, B.P., Kretser, W.A., Sharpe, W.E., 1996. 499 Episodic acidification of small streams in the northeastern United States : Fish mortality in $500 \quad$ field bioassays. Ecol. Appl. 6 (2), 408-421.

501 Weatherley, N.S., Ormerod, S.J., 1991. The importance of acid episodes in determining 502 faunal distributions in Wales. Freshwater Biol. 25, 71-84.

503 Wheatly, M.G., Gannon, A.T., 1995. Ion regulation in crayfish : freshwater adaptation and the 504 problem of molting. Amer. Zool. 35, 49-59.

505 Wigington, P.J.Jr., Baker, J.P., Dewalle, D.R., Kretser, W.A., Murdoch, P.S., Simonin, H.A., 506 Van Sickle, J., McDowell, M.K., Peck, D.V., Barchet, W.R., 1996. Episodic acidification 507 of small streams in the northeastern United States : Episodic Response Project. Ecol. Appl. $508 \quad 6(2), 374-388$.

509 Willoughby, L.G., 1988. The ecology of Baetis muticus and Baetis rhodani (Insecta, 510 Ephemeroptera), with special emphasis on acid water backgrounds. Int. Rev. Ges. $511 \quad$ Hydrobiol. 73, 259-273.

512 Willoughby, L.G., Mappin, R.G., 1988. The distribution of Ephemerella ignita 513 (Ephemeroptera) in streams : the role of $\mathrm{pH}$ and food resources. Freshwater Biol. 19, 145$514 \quad 155$.

515 Wood, C.M., \& Rogano, M.S., 1986. Physiological responses to acid stress in crayfish 516 (Orconectes) : Heamolymph ions, acid-base status, and exchanges with the environment. 517 Can. J. Fish. Aquat. Sci. 43, 1017-1026. 
518 Wood, C.M., 1989. The physiological problems of fish in acid water. In: Morris, R., Taylor,

519 E.W., Brown, D.J.A., Brown, J.A. (Eds.), Acid toxicity and aquatic animals. Cambridge 520 University Press, Cambridge, pp 125-152.

521 Wright, D.A., Frain, J.W., 1981. The effect of calcium on cadmium toxicity in the freshwater 522 amphipod, Gammarus pulex (L.). Arch. Environm. Contam. Toxicol. 10, 321-328. 
541 Table 1. Mean and SD values of chemical parameters of each exposure stream $(n=4)$. ANC:

542 Acid Neutralizing Capacity.

\begin{tabular}{|c|c|c|c|c|c|c|}
\hline & \multicolumn{2}{|c|}{ La Maix } & \multicolumn{2}{|c|}{ Ravine } & \multicolumn{2}{|c|}{ Gentil Sapin } \\
\hline & Mean & SD & Mean & $\mathrm{SD}$ & Mean & $\mathrm{SD}$ \\
\hline $\mathrm{pH}$ & 7,3 & 0,0 & 5,5 & 0,1 & 4,5 & 0,1 \\
\hline $\operatorname{ANC}\left(\mu\right.$ eq $\left.1^{-1}\right)$ & 599,3 & 10,4 & 5,5 & 3,5 & $-19,4$ & 6,5 \\
\hline conductivity $\left(\mu \mathrm{S} \mathrm{cm}^{-1}\right)$ & 78,6 & 2,2 & 30,5 & 2,0 & 29,9 & 1,0 \\
\hline Temperature $\left({ }^{\circ} \mathrm{C}\right)$ & 10,3 & 0,3 & 11,9 & 0,5 & 12,9 & 0,5 \\
\hline $\mathrm{Ca}^{2+}\left(\mu \mathrm{mol} \mathrm{l}{ }^{-1}\right)$ & 281,7 & 5,2 & 55,9 & 5,6 & 38,8 & 0,8 \\
\hline $\mathrm{Mg}^{2+}\left(\mu \mathrm{mol} 1^{-1}\right)$ & 187,1 & 4,7 & 35,7 & 2,4 & 25,9 & 1,3 \\
\hline $\mathrm{Na}^{+}\left(\mu \mathrm{mol} \mathrm{l} 1^{-1}\right)$ & 47,6 & 0,0 & 52,0 & 4,8 & 37,0 & 2,0 \\
\hline $\mathrm{K}^{+}\left(\mu \mathrm{mol} \mathrm{l} \mathrm{l}^{-1}\right)$ & 45,7 & 0,6 & 42,5 & 2,7 & 25,7 & 0,8 \\
\hline $\mathrm{SO}_{4}{ }^{2-}\left(\mu \mathrm{mol} \mathrm{l} 1^{-1}\right)$ & 63,4 & 0,4 & 72,5 & 5,1 & 50,7 & 2,6 \\
\hline $\mathrm{NO}_{3}^{-}\left(\mu \mathrm{mol} \mathrm{l}{ }^{-1}\right)$ & 62,8 & 1,0 & 49,6 & 5,5 & 80,3 & 3,4 \\
\hline $\mathrm{Cl}^{-}\left(\mu \mathrm{mol} 1^{-1}\right)$ & 38,7 & 1,2 & 42,2 & 2,5 & 32,1 & 1,4 \\
\hline Total Al $\left(\mu \mathrm{mol} \mathrm{l}^{-1}\right)$ & 0,4 & 0,2 & 4,4 & 4,8 & 15,9 & 1,3 \\
\hline
\end{tabular}


558 Table 2. Summary of 2-way analysis of variance. F, F ratio; p, probability; d.f., degrees of

559 freedom; n.s., not significant.

560

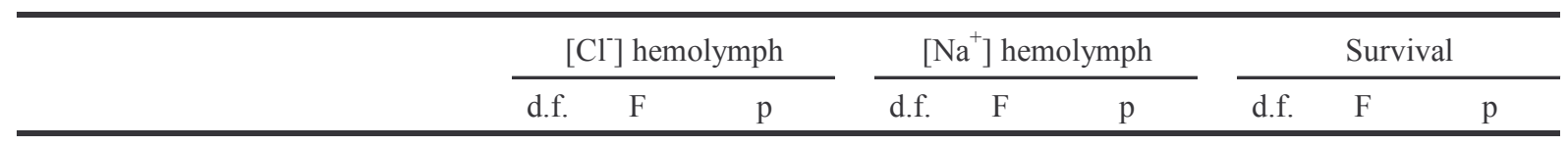

a) Exposure effect

Factor a (Stream) $\quad 2 \quad 34,1 \quad \begin{array}{llllllll}\mathbf{1 0}^{-3} & 2 & 46,2 & <\mathbf{1 0}^{-3} & 2 & 110,4 & <\mathbf{1 0}^{-3}\end{array}$

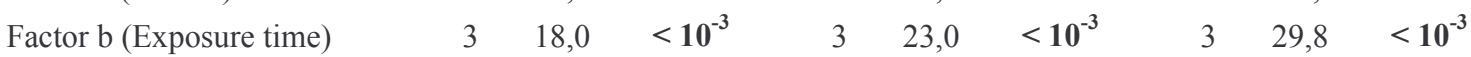

Interaction $\quad \begin{array}{lllllllll}6 & 4,6 & <\mathbf{1 0}^{-3} & 6 & 6,7 & <\mathbf{1 0}^{-3} & 6 & 20,0 & <\mathbf{1 0}^{-3}\end{array}$

b) Recovery effect

Slightly acid exposure (Ravine)

Factor a (Exposure time)

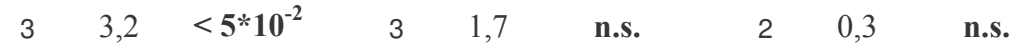

Factor b (Recovery time)

$5 \quad 14,1<\mathbf{1 0}^{-3} \quad 5 \quad 17,5 \quad<\mathbf{1 0}^{-3} \quad 5 \quad 2,9 \quad<\mathbf{5}^{*} \mathbf{1 0}^{-2}$

Interaction

$15 \quad 2,0 \quad<\mathbf{5}^{*} \mathbf{1 0}^{-\mathbf{2}} \quad 15 \quad 3,2 \quad<\mathbf{1 0}^{-\mathbf{3}} \quad 10 \quad 0,3 \quad$ n.s.

Strongly acid exposure (Gentil sapin)

$\begin{array}{llllllllll}\text { Factor a (Exposure time) } & 3 & 3,9 & <\mathbf{5}^{*} \mathbf{1 0}^{-\mathbf{2}} & 3 & 0,5 & \text { n.s. } & 2 & 11,7 & <\mathbf{1 0}^{-3}\end{array}$

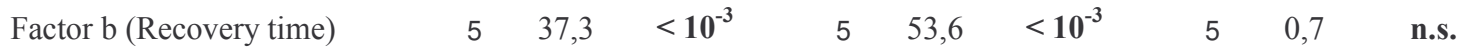

Interaction

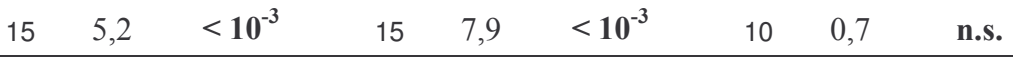

562

563

564

565

566

567

568

569

570

571 

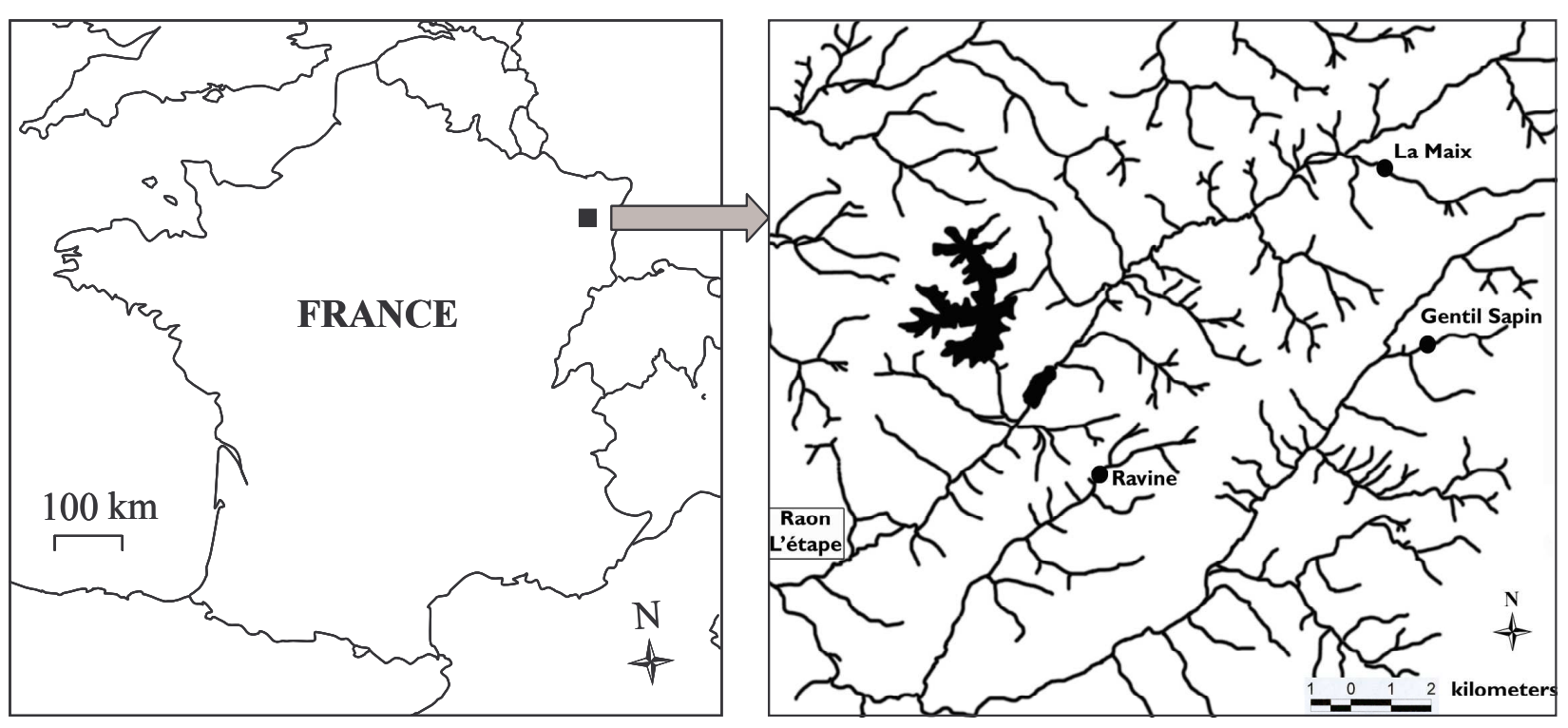

573

574

Figure 1. Location of the 3 study sites in north-eastern France. 

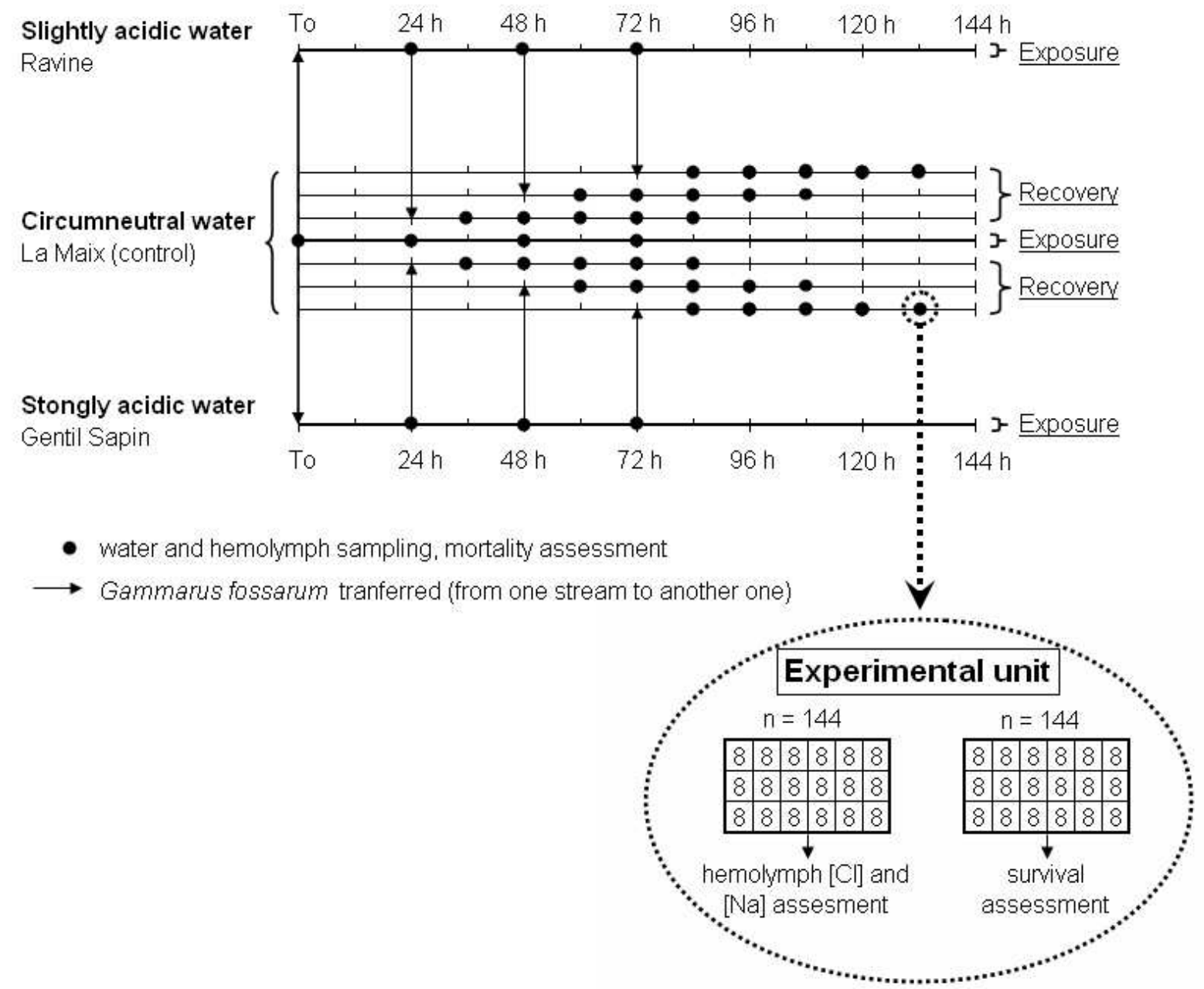

591 Figure 2. Experimental design of the exposure and recovery experiment 
(a) $\square$ Circumneutral stream (La Maix) $\square$ Slightly acid stream (Ravine) $\quad$ Strongly acid stream (Gentil Sapin)

602

603

604

605

606

607

608

609

610

611

612

613

614

615

616

617

618

619

620

621

622

623

624

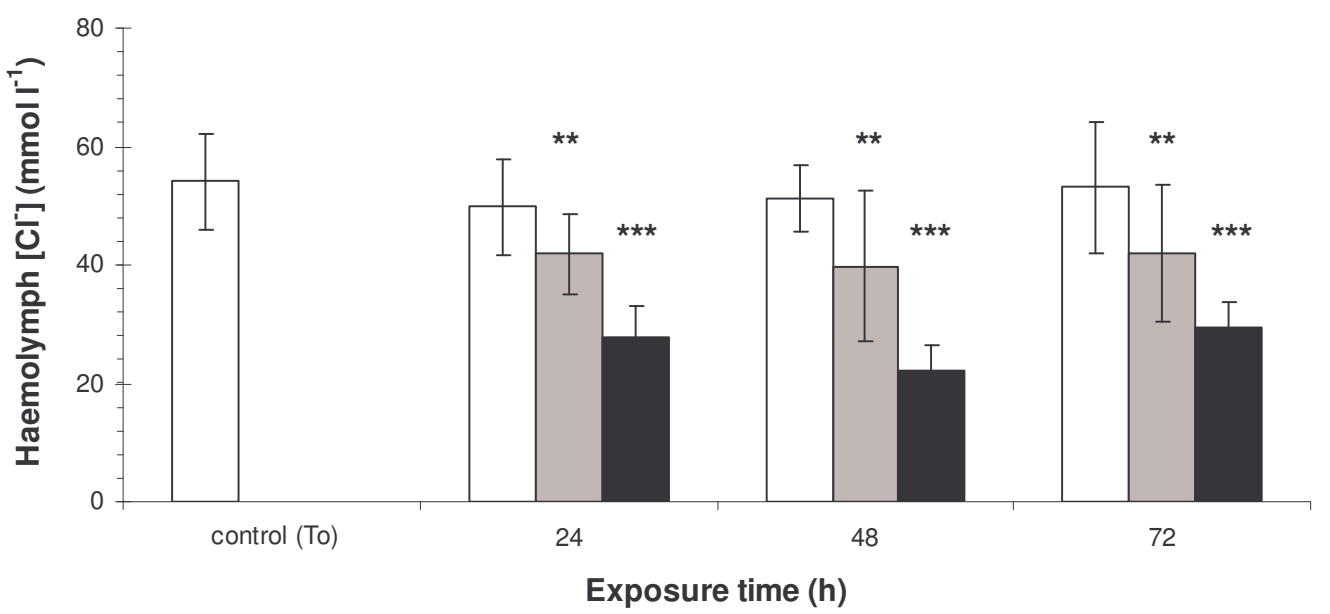

(b) $\square$ Circumneutral stream (La Maix) $\square$ Slightly acid stream (Ravine) $\quad$ Strongly acid stream (Gentil Sapin)

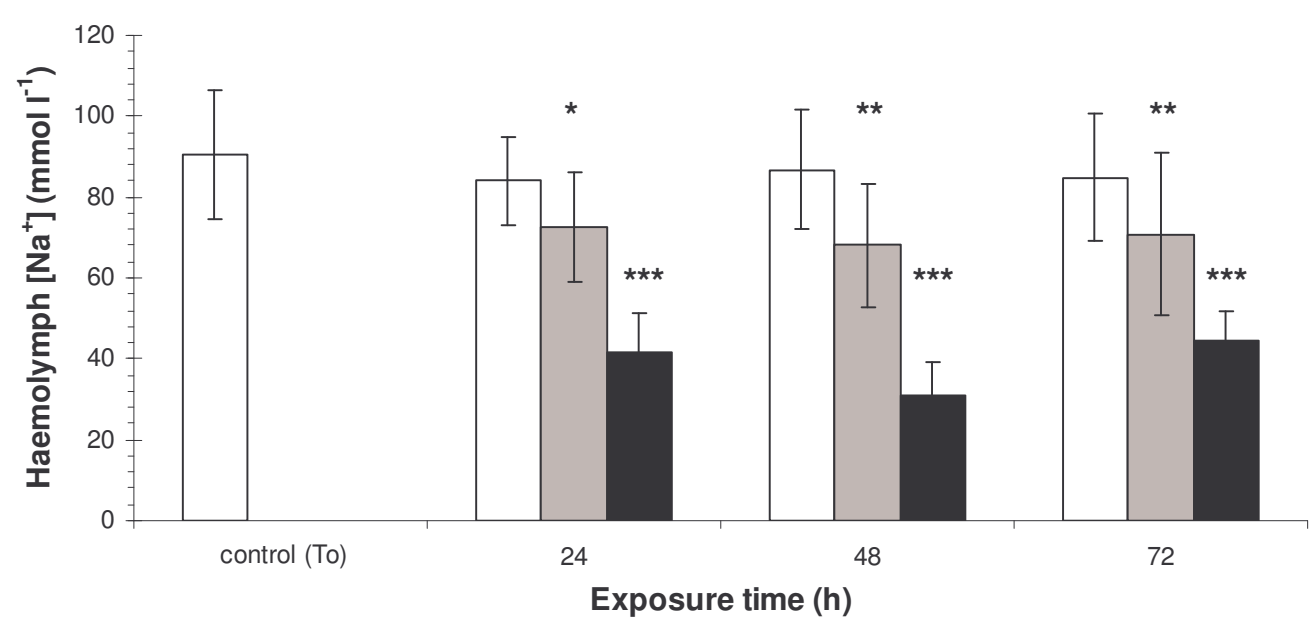

(c) $\square$ Circumneutral stream (La Maix) $\square$ Slightly acid stream (Ravine) $\square$ Strongly acid stream (Gentil Sapin)

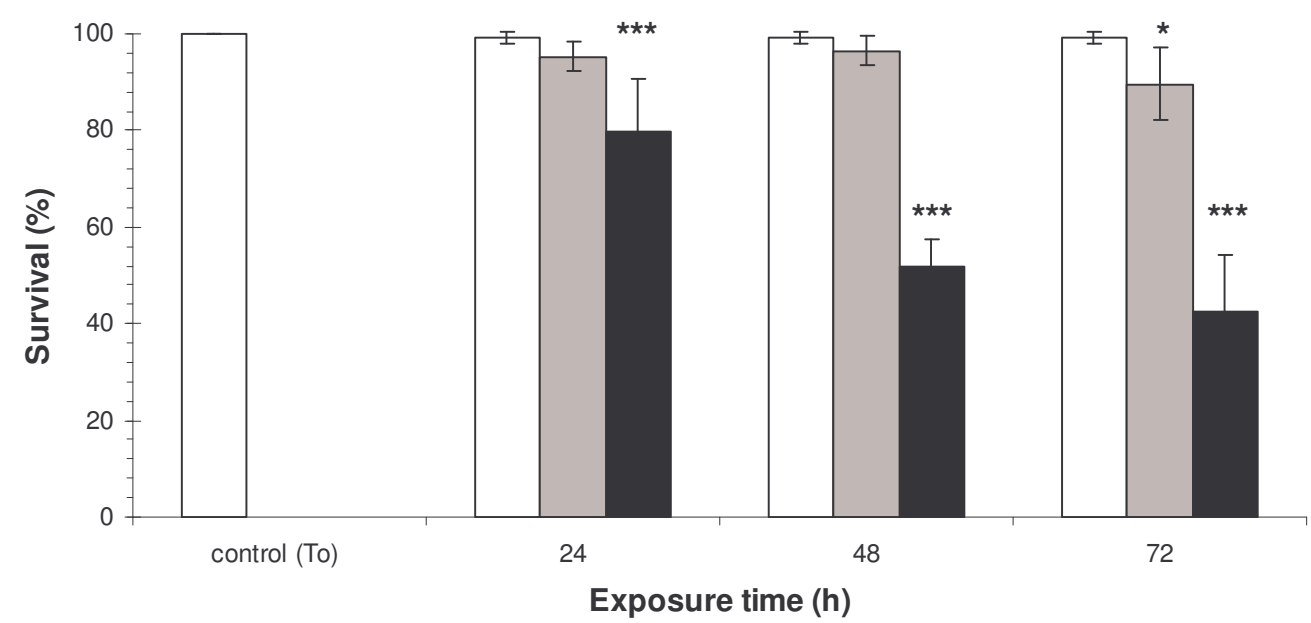

625 Figure 3. Mean ( $\pm \mathrm{SD})\left[\mathrm{Cl}^{-}\right]$haemolymph (a), $\left[\mathrm{Na}^{+}\right]$haemolymph (b), and survival (c) of 626 Gammarus fossarum exposed to circumneutral, slightly and strongly acidic streams waters. 627 Significant differences against $\mathrm{T}_{0}$ are indicated by asterisks (Ficher's Least Significant 628 Difference test; $*$ : $<<0.05 ; * *: p<0.01 ; * * *: p<0.001)$. 


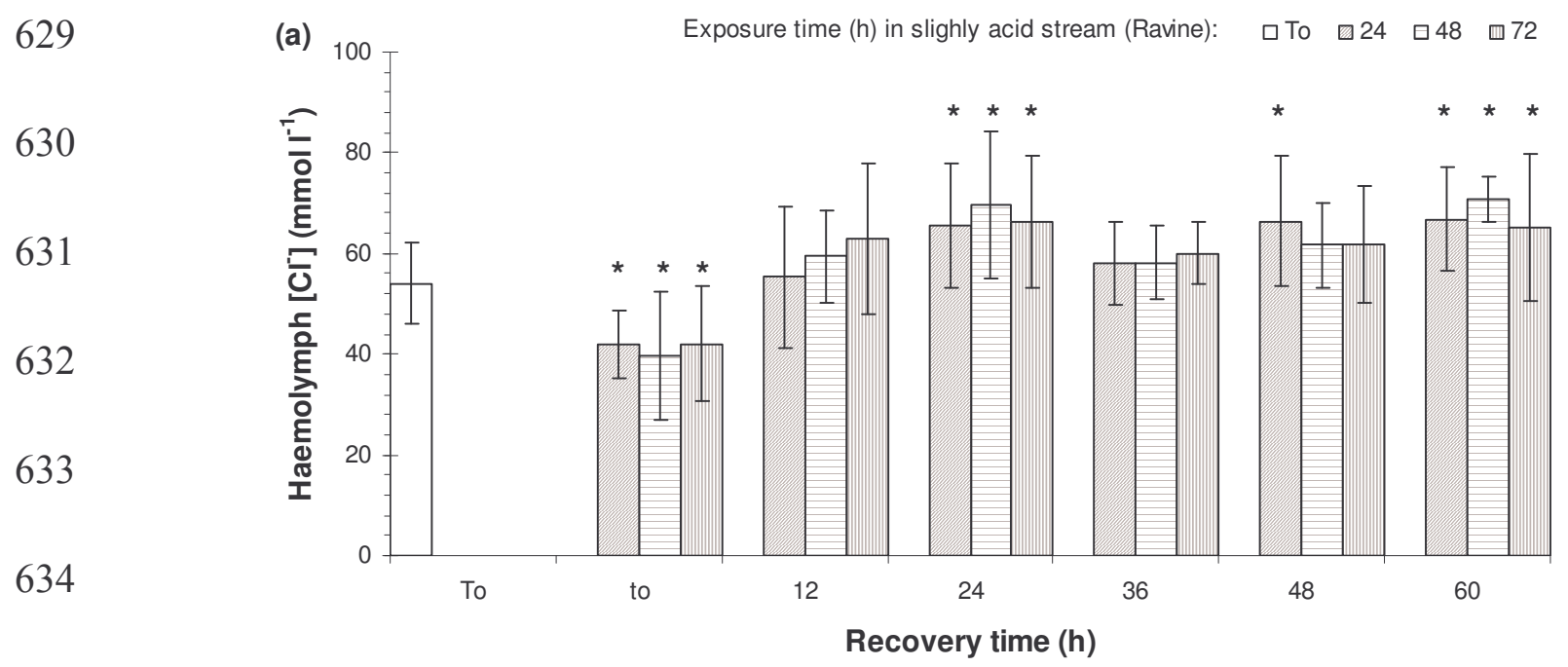

635

636

638

(b) 140

Exposure time (h) in slighly acid stream (Ravine): $\quad \square$ To $\quad \square 24 \quad \square 48 \quad \square 72$

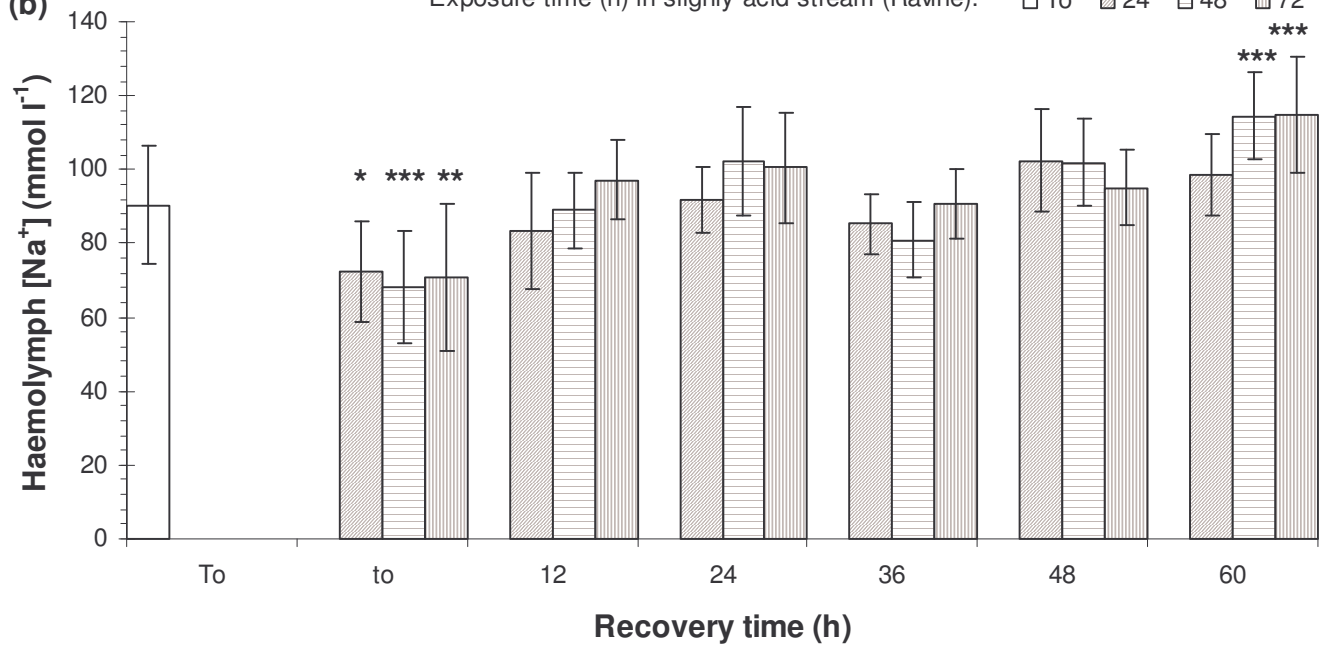

642

(c)

Exposure time (h) in slighly acid stream (Ravine):

$\square 24 \square 48 \square 72$

643

644

645

646

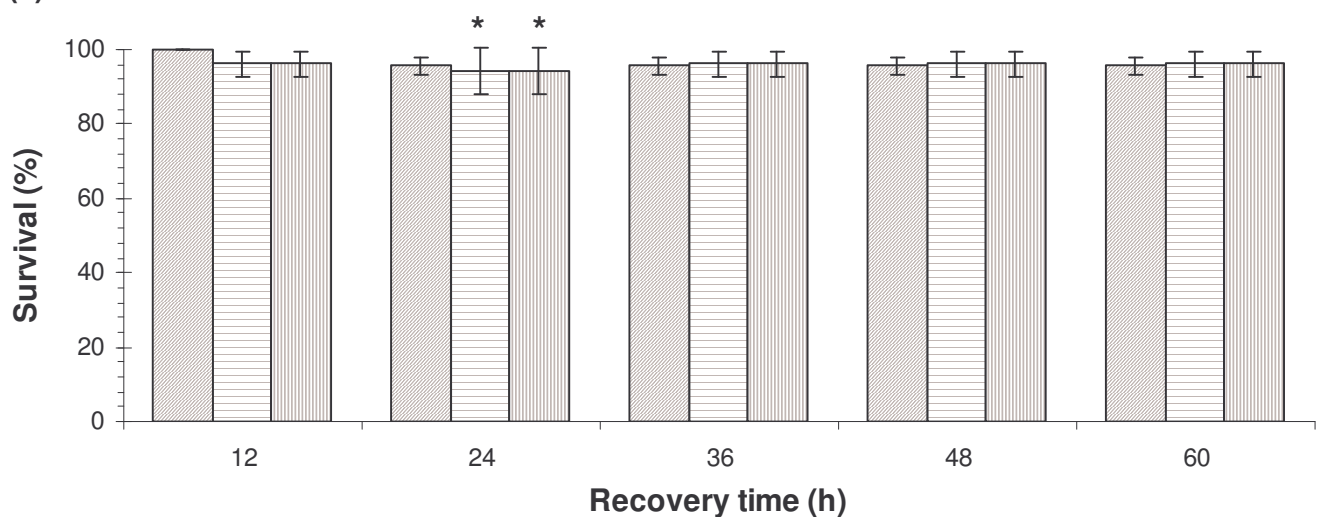

647 Figure 4. Mean $( \pm \mathrm{SD})\left[\mathrm{Cl}^{-}\right]$haemolymph (a) and $\left[\mathrm{Na}^{+}\right]$haemolymph, (b) and survival (c) of 648 Gammarus fossarum exposed to slightly acidic waters (Ravine) and transferred in the 649 circumneutral stream (La Maix) to test recovery capacity. Significant differences against $\mathrm{T}_{\mathrm{o}}$ 650 are indicated by asterisks (Ficher's Least Significant Difference test; *: $p<0.05 ; * *: p<0.01$; $651 * * *: p<0.001) . \mathrm{t}_{\mathrm{o}}$ represents the last exposure time before organism transfer in circumneutral 652 stream. 
653

654

655

656

657

658

659

660

661

662

663

664

665

666

667

668

669

670

671

672

673

674
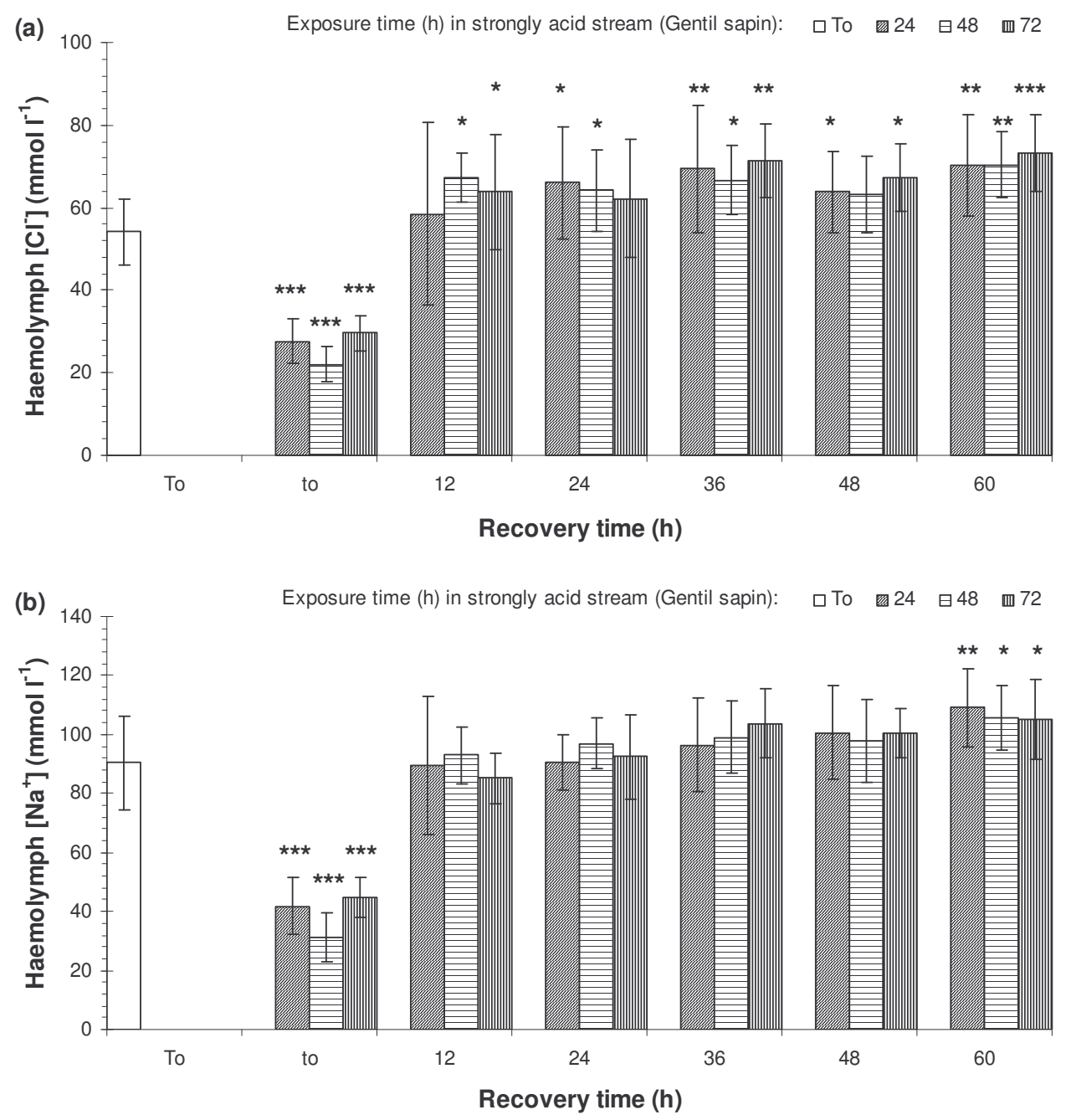

(c)

Exposure time (h) in strongly acid stream (Gentil sapin): 四24白 48 四 72

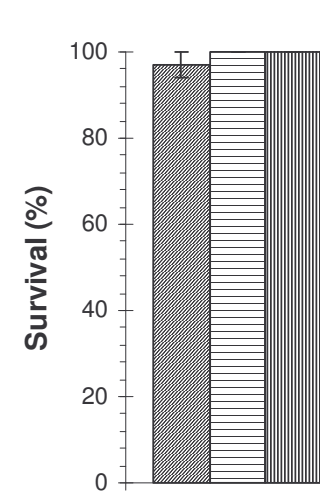

12

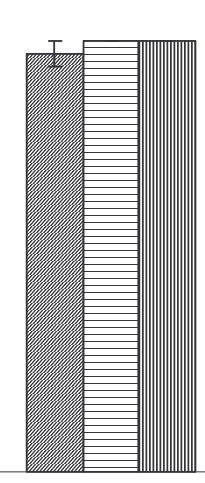

24

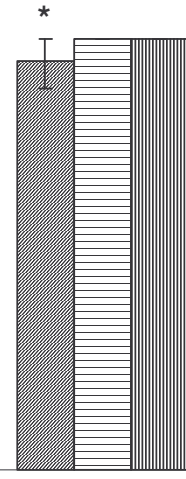

36

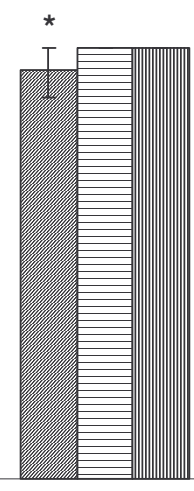

48

Recovery time (h)

675 Figure 5. Mean ( \pm SD) $\left[\mathrm{Cl}^{-}\right]$haemolymph (a) and $\left[\mathrm{Na}^{+}\right]$haemolymph, (b) and survival (c) of 676 Gammarus fossarum exposed to strongly acidic waters (Gentil sapin) and transferred in the 677 circumneutral stream (La Maix) to test recovery capacity. Significant differences against $\mathrm{T}_{0}$ 678 are indicated by asterisks (Ficher's Least Significant Difference test; *: $p<0.05 ; * *: p<0.01$; $679 * * *: \mathrm{p}<0.001) . \mathrm{t}_{\mathrm{o}}$ represents the last exposure time before organism transfer in circumneutral 680 stream. 